1) 高野：本誌 $56,451,(1961)$

\title{
考支 献
}

2) 照井等 : $35,105(1957), 36,109(1958)$ 本誌 $56,408(1961)$

3) 山田：本格 56,416(1961)

4) 川田：本誌 $56,438(1961)$

5) 井上等 : 本誌 $55,713(1961)$

6) 河村, 山下等 : 本誌 54,585 (1959)

7) 本誌 $56,426(1961)$

8）伊藤：「清配醸造の実態」話題集，各流派に関するシンポジゥムにて発表，53，(1959）

9) 鼓等：本誌 $55,529(1960)$

10) 小川等: 本誌 $56,163(1961)$

11) 伊藤等 : 本誌 $52,893(1957)$

12) 陰山等：酸工 $32,68(1954) ， 33 ， 28(1955)$, 醸造論文集第 11 輯，42(1955)

13) 鈴木等：日本数芸化学会講演要旨 62(1957)

14) 蒲池等: 本誌 $52,815(1957)$

15）鼓等：本誌 $55,529(1960)$

16) 井上等: 本誌 $55,713(1960)$

17) 河村, 山下等：本誌 55,785 (1960)

18）小川等：本誌 $56,163(1961)$

19）陰山等: 酸工 $33,112(1955)$

\section{米楝のプロテアーゼに関する研究(第5 報)}

酒造工程中に拈けるプロテアーゼの消長

布 川弥太郎*, 難波康之祐*, 渡辺捷栄*

(昭和 36 年 8 月 1 日受理)

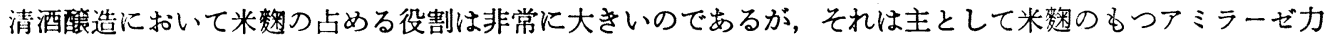
に依存していると考兄られる。併し清酒の香味を論ずる場合には, 米麴中に存在する蛋白質分解酵素のもつ 意義を無視するわけにはいかない。

清酒酾造と米数プロテアーゼを結びつけて研究した報告は割合に少なく, 酒母中の窒素物とプロテアーゼ の関係を論じた菍山, 杉田等 ${ }^{1)}$, 秋山ら 2$)$ の研究, 醪中のプロテアーゼの消長を調べた栗山ら ${ }^{3)}$ の研究が報 告されているに過ぎない。著者らもプロテアーゼを多く生成させる為の米麭の培養条件を検討した結果, 低 温で培養した策の方が力価の強い事を見出し4)，濃味のある清酒を䤑造する為には低温培養㛫を使用すべき 事を提唱し, 又醪中のプロテアーゼの消長を追跡し, 酸性プロテアーゼ醪期間中比較的安定である事を認め, 更に酒母中に拁ける米数のプロテアーゼ系の消長を $\mathrm{pH}$ 作用曲線により検討し，プロテアーゼは酒 母中に おいてもかなり安定である事を知っだ)。

さて，著者ら゙は醪中において酸性プロテテーゼのみが安定に残るのであるが，それは電気泳動的に明ら

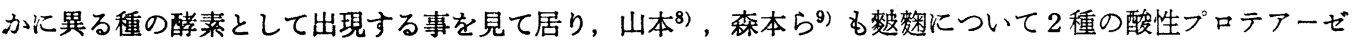
の存在を証明し, 更に森本ら $\left.{ }^{10}\right)$ にって米麭抽出液について酸性プロテアーゼの多様性が認められ，これは 最初単一と考えられる酵素が transfurmation を受けていくつかの成分に遂次的に変化するすすのであろう と推定された。かくの如く $\mathrm{pH} 3.0$ に至適 $\mathrm{pH}$ を持つ酸性プロテアーゼであっても数種の成分として存在 する事が明らかになったのであるが，前記の如き至適 $\mathrm{pH}$ における力価測定や $\mathrm{pH}$ 作用曲線によるプロテア 一ゼの消長追跡によっては, 果して酒造工程中に㥂ける酸性プロテアーゼが性質の変化を受けて行くもので

\section{* 国税庁醇造試験所}


あるかどうかといった事を調べる事は出来ない。更にはプロテアーゼ相互間の影響力を避けて検傠を進める 為にも夫々のプロテアーゼを単離して検討して行く事が要求されるに至った。著者らはDEAE-cellulose を 用いて米憗という非常にプロテアーゼ含量の少ない材料からプロテアーゼを分離濃縮する方法を設定した 為 ${ }^{11)}$ 酸性プロテアーゼ系**及びアルカリ性プロテアーゼを分離する事が容易になったので，酒造工程中即ち 製憗からはじまって上槽に至るまでの各段階について，試料から夫々酸性及びアルカリ性プロテアーゼを分 離濃鏥し，更に電気泳動を行って，各プロテアーゼの性質が途中で変化して泳動図に変化を来たすか否かを 調べだ。

**[注]酸性プロテアーゼ系なる言葉を使つたのは，米教の酸性プロテアービは往くにして 2 〜の成分 としていわれる事及び微量の中性プロテアーゼを含んでいるからである。

\section{実 験 方 法}

\section{1 試料の調整}

i) 药尔

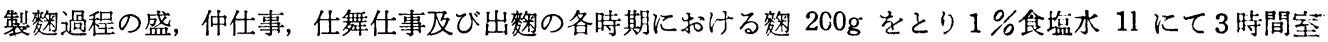
温で抽出後, 濾過し試料とした。

ii） 酒母及び醪

酒母製造過程の湧付及び枯し時に括ける酒母 $700 \mathrm{~g}$ をとり，3\%食塩水 $200 \mathrm{ml}$ にて 3 時間抽出後濾過し 試料とする。

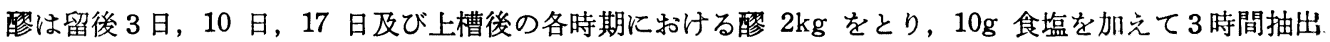
後濾過し試料とする。

\section{2 プロテアーセの分離湿縮法}

上記の如くして調整した試料は一夜流水透析後次の手順により DEAE-cellulose カラムにより酸性プロ テアーゼ系とアルカリプロテアーゼとに分離，更に冷凍乾燥を行って濃縮試料を得た。

\section{第 1 図 DEAE-cellulose にする酵索の分離手順}

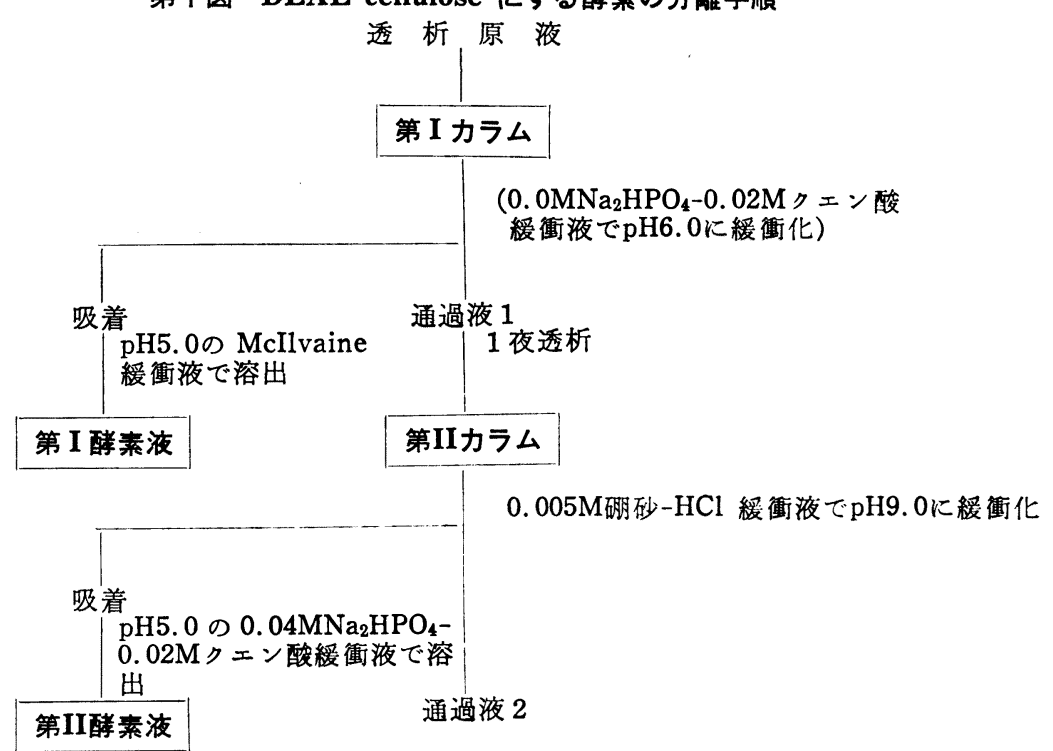

DEAE-cellulose による吸着及び溶出の手順は第 1 図に示してある。そして便宜的に第 I カラムに吸着さ

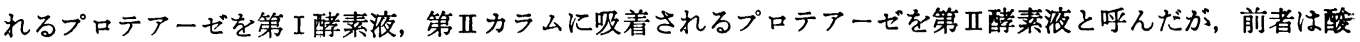

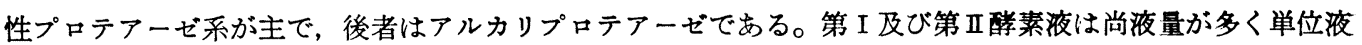
量当りの力価が小さいので 1 夜流水透析後真空冷涷乾燥機にかけて更に濃樎した。

\section{3 電気泳動}

上の方法によって得た濃縮第 I 及び第II液は澱粉を支持体とする電気泳動にかけて泳動図を作製した。

i）澱粉の洗涤

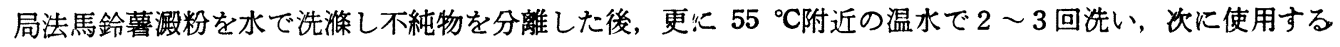
緩衝液( $\mathrm{pH} 6.0$ の $\mathrm{M} / 80$ 燐酸緩衝液) で, pH6.0 になる迄洗滌した。 
ii) 泳動条件

電極室には $1 \% \mathrm{KCl}$ を入れ，電極室と緩衝液槽との連絡には，1％ $\mathrm{KCl}$ 寒天ブリッヂを用いた。泳動条 件は時により多少異っているがほぼ 400volt の定電圧, 20 時間である。

iii）泳動困の作製

涾動終了後 $2 \mathrm{~cm}$ 間隔で溉粉柱を切り取り，水を加えて抽出した液を酵素液とし，プロテアーゼ活性，ア ミラーゼ活性及び蛋白質量を測定して泳動図を作製した。

プロテアーゼ活性の測定は常法により ${ }^{12)}$, 第 I 酵素液については $\mathrm{pH} 3.0$ 又び $\mathrm{pH} 6.0$ の活性を, 第 II 酵 素液については $\mathrm{pH} 9.0$ 及び 6.0 の活性を測定した。尚反応条件としては, 酵素液 $1 \mathrm{ml}$ を $37{ }^{\circ} \mathrm{C} 1 \sim 2$ 時

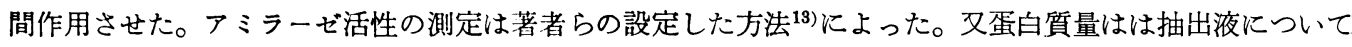

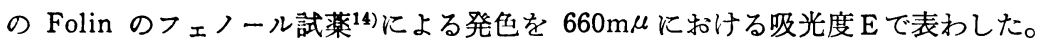

\section{実験結果及び考察}

1
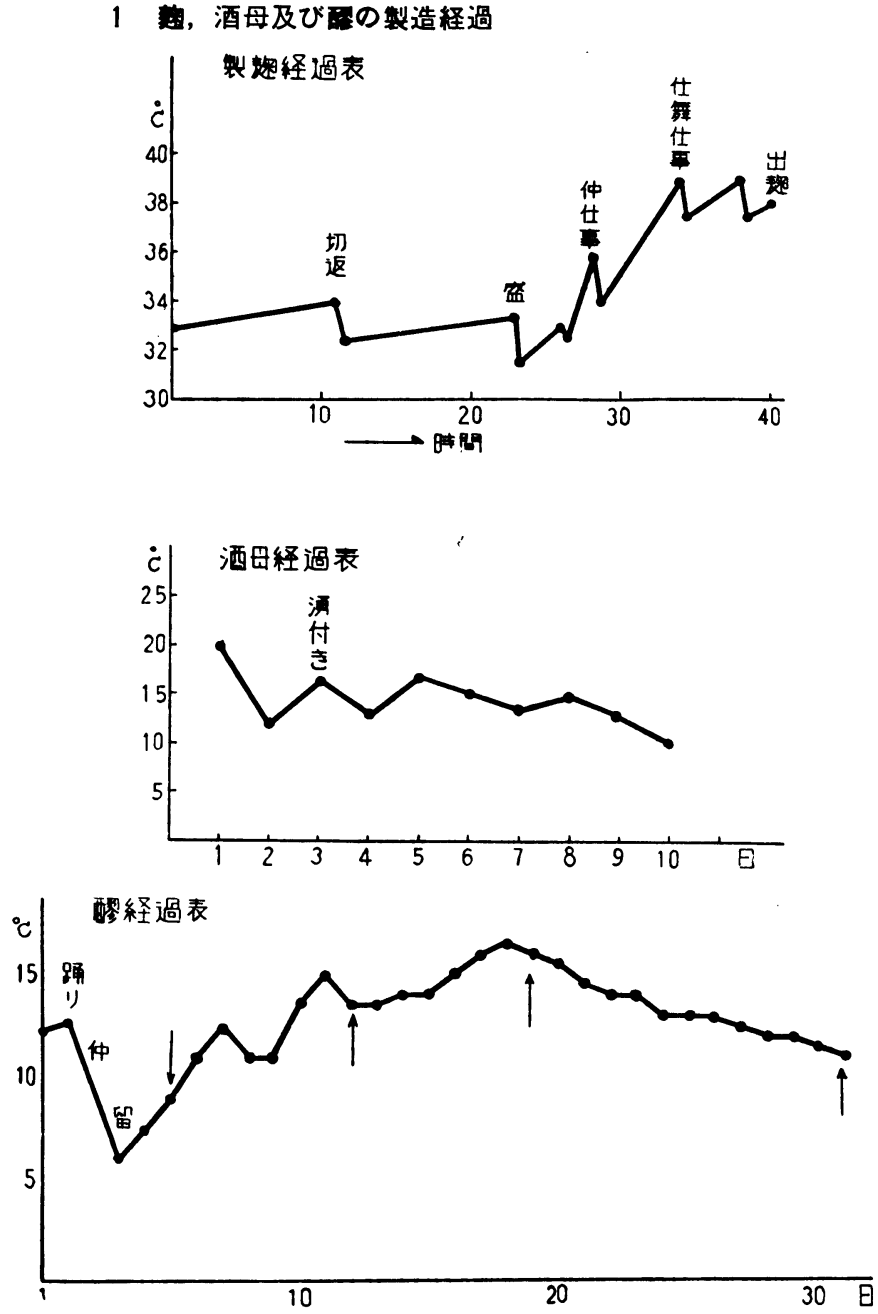

第 2 図

，酒母及ひ間の品温経過
各工程の品温経過は第 2 図に又酒母 及び醪の成分分析結果は第 1 表に示し てある。尚第 2 図中の矢印は試料採取 点を, 又第 1 表中の太字も試料採取時 期を夫々示してある。

\section{2 湿縮試料の力価}

抽出原液及び最終濃縮試料について の各酵素活性度は第 2 表に示してある。 辂の抽出液量は各段階につきほぼ一定 であるが，酒母及び醪は溶解状態が異 る為, 各段階によって抽出液量は大き く異っている。又最終濃縮液量も異る ので, 夫々の值をるあわせて表示した。 表示してある如く, 分離濃縮夜の力価 が非常に減少している事は，この結果 から時間の経過に伴 万活性度の量的な 関係を測定する事が非常に困難である。 この原因として, 酵素液の保存期間が かなり長かった為に（冷蔵庫中約 1 ケ 月),酵素蛋白の変性による失活を来た したすのと考兄られる。然し，埸につ いて酸性プロテアーゼは仕舞仕事前後 から急速に增加しはじめる事とアルカ リ性プロテアーゼが仕舞仕事の頃一旦 消失して後再び現われる事が認められ る。次江酵素液の $\mathrm{pH} 3.0$ と $\mathrm{pH} 6.0$ の活性の相対比が大き変動し, 抽出 原夜の $\mathrm{pH} 3.0$ と $\mathrm{pH} 6.0$ の活性の相 対比々濃縮液のそれとは同じでなく全 く逆の関係になっている場合のある事が注目される。つまり $\mathrm{pH} 3.0$ の活性と $\mathrm{pH} 6.0$ の活性の失活程度が まちまちであるということであり，若し両活性が同一の酵素蛋白によって測定されると考えるなら，両活性 の失活度は同じであるはずであるから，この $\mathrm{pH} 3.0$ の活性の失活の方が大であるという事はこの酵素液中 に中性プロテアーゼが混入しているという疑問が生ずるが, 次の電気泳動による検討では, 両活性が同じ位 置に移動する事を証明したので，同一醅素中に $\mathrm{pH} 3.0$ で作用し得る活性基と $\mathrm{pH} 6.0$ で働き得る活 性基と が含まれているといら可能性も考えられるが，この点関しては今後研究を進めたい。同様な傾向は，アル カリ性ピロテアーゼについても多少認められる。一方アルカリ性プロテアーゼはその含量が少量であるが， 
第 1 表 醪の成分分析表

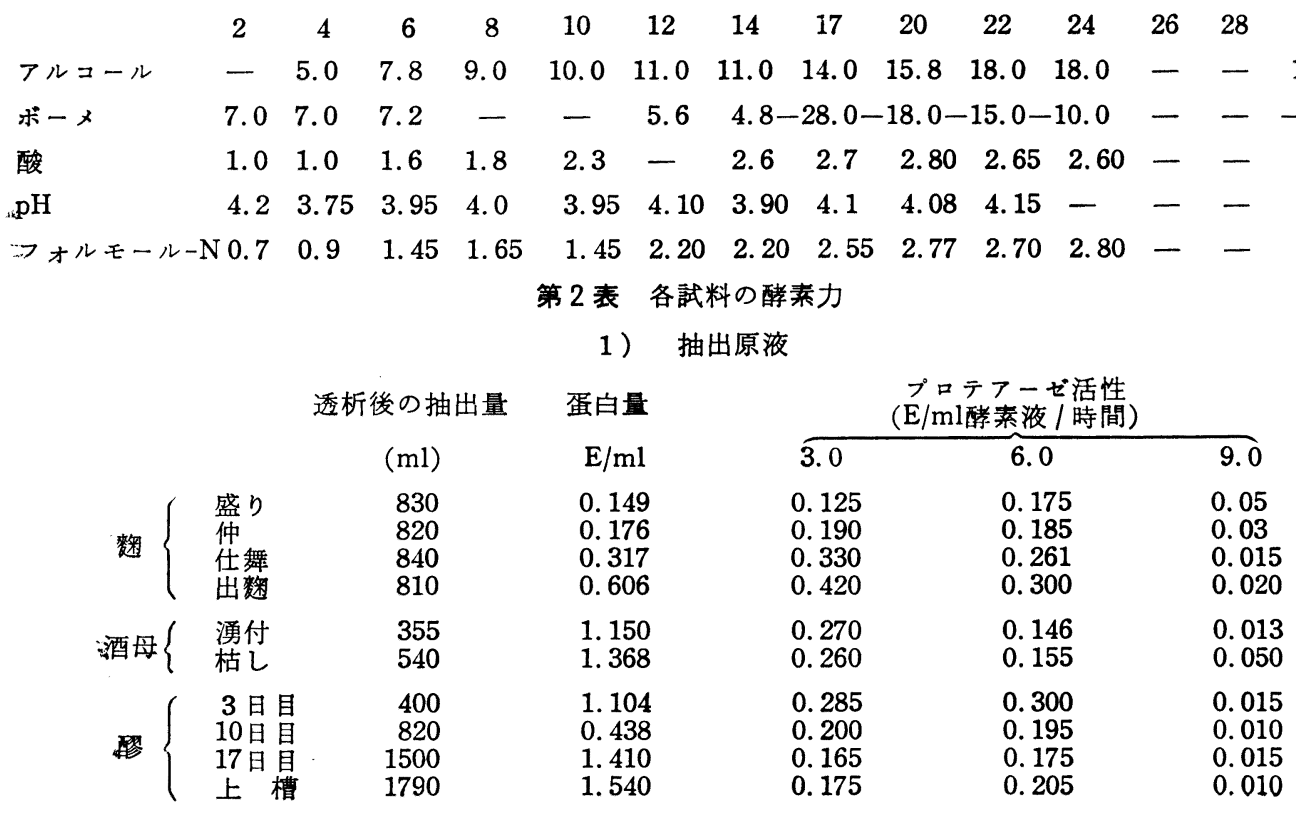

\section{2）分離濃縮液}

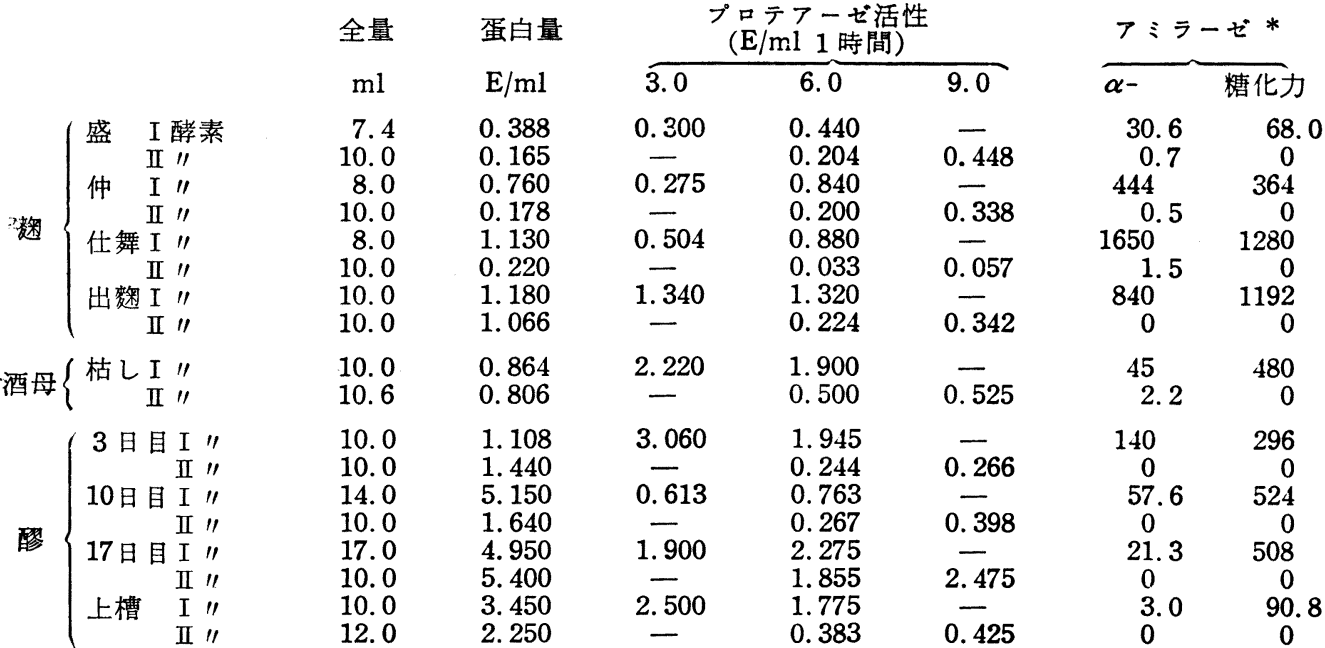

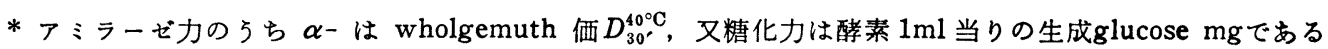
酒母及び醪中においても酸性プロテアーゼに劣らずかなり安定に存在している事が判明した。

\section{3 電気泳動図の変化}

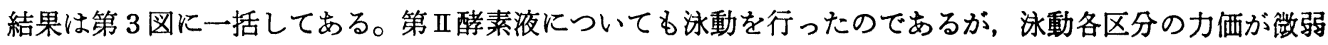
ではっきりした冰動図が求められなかった。

殞についてみると，盛りから出整に至るまで，酸性プロテアーゼ構成成分の変化はなく，既に盛り時に生 成された酸性プロテアーゼと出䊍時啭に蓄積されたプロテアーゼなどは同じ形の泳動図である様に考えられ る。従って少くとも製䔩過程中はプロテアーゼの transformation は行われず，ただ力価が增大するだけで あると推論された。 pH6.0 の活性が仕舞仕事までは pH3.0 の活性より大きいとい5事については，先に記 述した理由から大きな意味を持たないものと考えられ, プロテアーゼの変性失活に対しては, 前記と同じ考 察がなされるのである。

transformation が行われないのは更に酒母及び醪中においても同じであり，醪 17 日目においてもただ 一つのピークしか認める事が出来なかった。然し上槽時になると泳動図に変化を生じ，今迄見られた一側の 大きなピークの他に原点附近から十側にピークが生じてくるのが見られ，やはり森本らの報告している様な 
第 3 図各区分の電気泳勒図

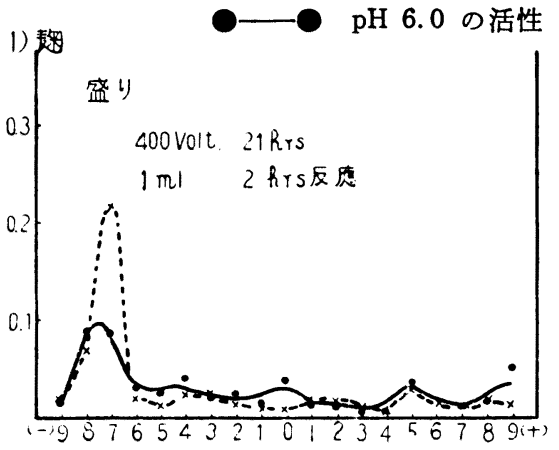

…… $\mathrm{pH} 3.0$ の活性
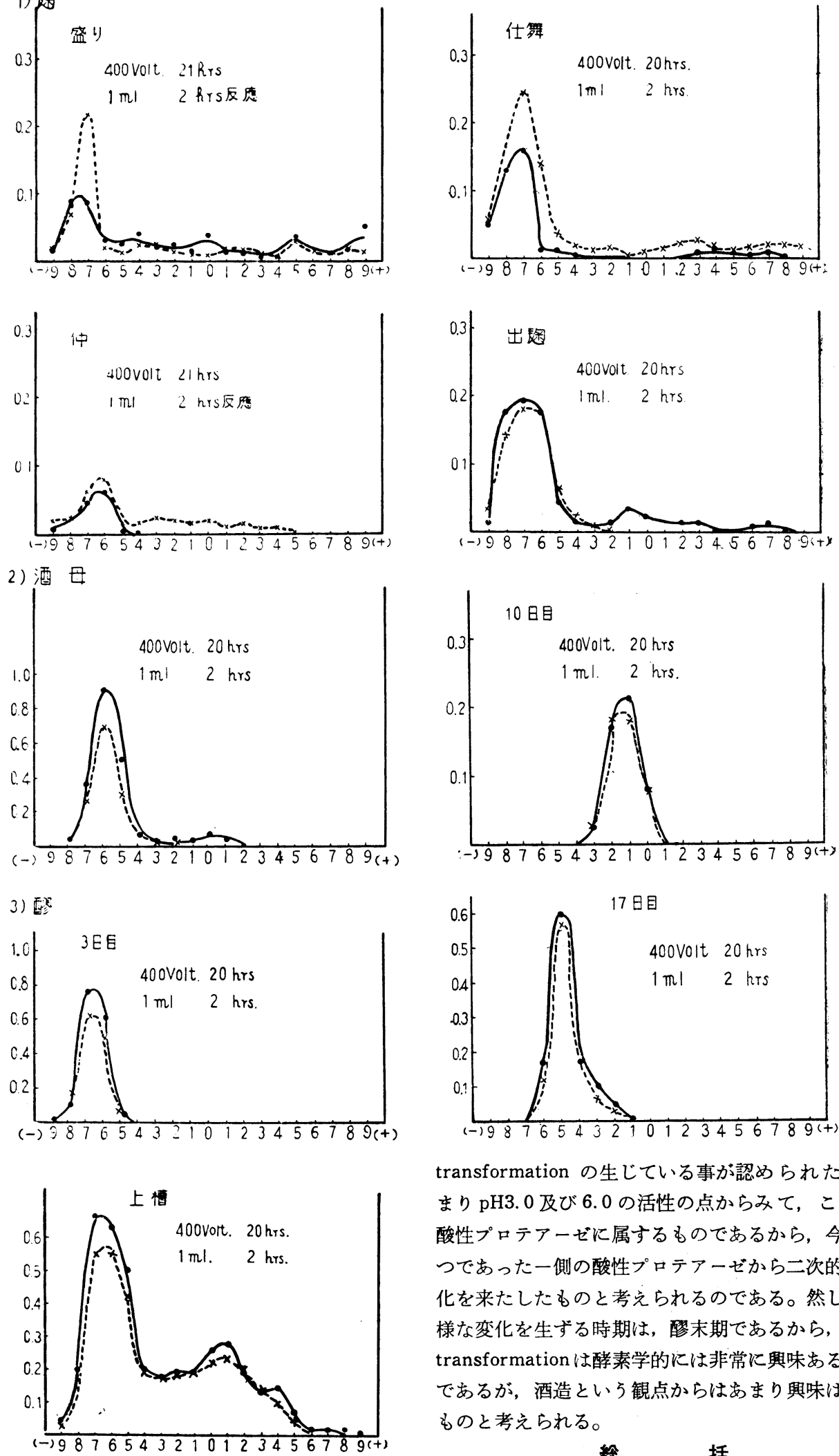

transformation の生じている事が認められた。つ まり $\mathrm{pH} 3.0$ 及び 6.0 の活性の点からみて, これも 酸性プロテアーゼに属するものであるから，今迄一 つであった一側の酸性プロテアーゼから二次的に変 化を来たしたものと考えられるのである。然しこの 様な変化を生ずる時期は, 醪末期であるから,この transformation は酵素学的には非常に興味ある現象 であるが，酒造という観点からはあまり興味はない ものと考えられる。

1) 製夜過程, 酒母及び醪育成過程において, プ 
ロテアーゼが如何なる変化を辿るかを知る為に，各段階の抽出醳素液をDEAE-cellulose 吸着法により，酸 性及びアルカリ性プロテアーゼを含む区分に分離しこれを更に冷凍乾燥を行って濃縮し，電気赤動を行って 泳動図の変化を調べた。

2）酵素の分離濃縮過程及び濃縮酵素液保存中において醭素活性はかなり失活し，しかも酸性プロテアー ゼの $\mathrm{pH} 3.0$ 及び 6.0 の活性は, その失活比が相関連していない様であって, 酸性プロテアーゼ中に中性プ ロテアーゼの混入している事が予想された。

3）電気泳動による泳動図の解析から，両活性は常に同一に行動している事が認められた。又麴の各試料 についての酵素活性はまちまちで量的関係は判然としないが, 移動距離はすべてほぼ同じで, 然も一つのピ 一クしか認められなかった事から, 製慗の初期に生成される酸性プロテアーゼと後期に生成される酸性プロ テアーゼとは本質的に同一のものである事が推定された。

4) 酒母及び殄についても酸性プロテアーゼは一つのピークとしてしか現われず, 余り構造的な变化は行 われない様に見受けられたが，上槽附近になると原点附近にピークが更に現われ，これは今迄一側沉存在し て居た酸性プロテアーゼが, transformation を起したものであろろと推測された。つまり酸性プロテアー ゼは酒母及び醪の中期までは殆んど変化なく存在しているが, 醪未期頃より少しづつ变化を来たし, 失活す るというよりはむしろ transformation を起すものと考兄らる。

文献

1) 蔭山：醇工 $33,53(1955)$

落山，杉田，国定：ibid 33，138(1956)

2) 秋山：農化 $31,913(1957), 32,355,526(1958)$

秋山，千野：本誌 $54,696(1959)$

3) 栗山, 今安, 口垣内: 醸工 $34,133(1956)$

4) 鈴木, 布川, 広島 : 本誌 $52,477,906(1957)$

5）鈴木，布川，広島，漆間，馬場，佐ヶ木：ibid. $56222(1957) ， 53 ， 160(1958)$

6）鈴木，布川，馬場，伊藤：本誌 $53,532(1958)$

7) 鈴木, 布川, 馬場, 本誌 $53,802(1958)$

8) 山本：農化関東支部第 1 回大会 $(1959,11)$

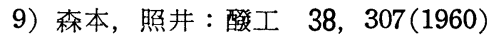

10) 森本, 照井, 醴工 39, 188(1961)

11）布川, 難波, 渡辺：農化大会, プロテフーゼシンポジゥムロ演, (1961，4)

12）蔭山，国定：䤃工 33，28(1955)

险山, 杉田: ibid 33, 109(1955)

13) 布川, 西谷, 荒木：本誌 $55,48(1960)$

14) M.L. ANSON : J.Gen. Physiol., 22, 79(1938)

アミノ酸のアルコール醊酵 第 9 報

左旋 パリン

山田 正一*古川敏 郎**

(昭和 36 年 7 月 25 日受理)

アルコール醸酵に於けるフーゼル油の成因については有名なフェリックス・エーリヒの研究があり ゼル油中に現われる高級アルコールはその物より炭素の一つ大きなアミノ酸が糖と共に酵母により酸酵され るときとのアミノ酸より生成する証としてロイシンよりイソアミルアルコール,イソロイシンより活性アミ ルアルコールを得ている。

この場合チロシン, フェニルアラニン, トリプトファンの如きも取扱っているがバリンについての記載の 無いのは当時ロイシン等から単離し難いこのアミノ酸を純粋に得る事が出来なかったためであろう。その後 震々教科書等にバリンからイソブチルアルコールの生成に関する化学式を揭げェーリヒの業樍の如く記した ものがあるが結局はそうなるすのにしてもこれはエーリヒの研究では無かった2)。

一方に括いてフーゼル油中には常成分として二種のアミルアルコール以外に正プロピルアルコールとイソ ブチルアルコールの存在は普通であり，この成因をつきとめなければならなかったのであるが前者はその沸

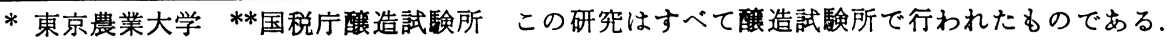

